\title{
THE DIRECTION OF SPACE REGULATION IN GLOBAL DYNAMICS
}

\author{
Agus Pramono \\ Faculty of Law, Diponegoro University, Indonesia \\ pramonoagus1955@gmail.com
}

\begin{abstract}
Space regulation initially acts as the orientation for activities in space which primarily concerns with research and development. As space exploration progresses, the regulation took a more practical direction which covers not only civil but also commercial activities. In line with this, development in commercial space activities took place such as telemetrics, remote sensor, space transportation, space industry, space tourism, space insurance, etc. To ensure that the commercialization of space activities is performed in a peaceful and safe manner as well as in ways that benefit all people, regulations in the form of anticipative laws are needed. These measures cover legal issues. Space commercialization is closely related to many aspects of life such as politics, social, economy, and security and defense which have been experiencing rapid development in that the presence of regulation for modern space law regime becomes an absolute necessity.
\end{abstract}

Keywords: space regulation, global dynamics

\section{Introduction}

Space regulation law can be approached by referring to the regulation of space exploration and exploitation Space Treaty 1967 and accompanying United Nations resolution before the enactment of the Space Treaty 1967 as well as regulations enacted after as compliments to the treaty. Although Space Treaty 1967 only covers the basic principles and have yet to define the delimitations between airspace and outer space, it has provided the direction for international cooperation in space for the sake peace and humanity between nations/countries ${ }^{1}$. Outer space is defined as the relatively empty portion of "The Universe," outside of the atmosphere of a celestial body. The term outer space in this study is in line with that of The Space Treaty 1967 and with the national regulation in Law Number 21 Year 2013 on Outer Space Affairs. The term is used to distinguish between airspace and terrestrial space which is a natural resource created by God Almighty, which is and will be explored and used sustainably for the good of all humanity.

Space Treaty 1967 is considered as the Magna Carta of Outer Space for All Nations ${ }^{2}$, Considering its fundamental and strategic nature which is oriented for peace and humanity. Outer space exploration and use are related to the Geo Stationary Orbit (GSO) natural resources and radio frequency spectrum as a communication resource. Priyatna Abdurrasyid explained that

\footnotetext{
${ }^{1}$ Agus Pramono, Dasar-Dasar Hukum Udara dan Ruang Angkasa, Bogor, Ghalia Indonesia, 2011, p. 5.

${ }^{2}$ Priyatna Abdurrasyid, Beberapa Bentuk Hukum sebagai Pengantar Menuju Indonesia Emas 2020, Jakarta: Fikahati Eneska, 2008, p. 287
} 
telecommunication satellites operate in orbit encircling Earth over the equator ${ }^{3}$. At the altitude of \pm $36,000 \mathrm{~km}$ above sea level, satellites naturally take stationary orbit. Hence, such orbit is called GSO.

Most outer space activities are performed by countries with advanced technology. However, developing countries have been able to carry out their outer space activities using international cooperation with industrious countries in the last decade.

The contrast in the aforementioned narrative clearly creates different positions on how countries view Space Treaty 1967 "which is initiated by UNCUPUOS (United Nations Committee on The Peaceful Uses of Outer Space)." Space Treaty 1967 is the international legal basis for outer space exploration and use, including the moon and other celestial bodies. Such endeavors are only possible to be carried out optimally by countries capable of developing and utilizing advanced technologies. Hence, technologically advanced countries have the potential as the first ones to seize the opportunities and reap the benefits of space use. On the other hand, developing countries, with all their limitations, become more of a follower. Hikmahanto Juwana stated that this "follower" status currently applies to Indonesia. The participation of Indonesia in some international treaties will incur obligations to Indonesia to amend several of her rules and regulations. One of such obligations is to transform the relevant international regulations into her national laws. ${ }^{4}$

The following discussions are focused toward the direction of outer space rules and regulations in global dynamics.

\section{Research Method}

This study is based on the research in the currently applied outer space regulations supported by some literature studies.

\section{Discussions and Results}

As an anticipatory measure for the issues in outer space activities and uses that may arise in the future, there are several legal issues which should be addressed. Observations on the development of human activities in land, water, and airspace, particularly in the development of its law and regulations, some correlation can be assumed. The most striking correlation can be seen in the institutionalization of legal regulations, particularly those with specific nature. It is common

\footnotetext{
${ }^{3}$ Ibid, p. 280

${ }^{4}$ Hikmahanto Juwana, Hukum Internasional dalam Perspektif Indonesia sebagai Negara Berkembang, Yarsif Watanpone, 2010, p. 51 360 
that regulations for commercial activities to be developed at a later stage in the form of special regulations. An example of this correlation would be the development of regulations on international civil air transportation known as the "Warsaw system" ${ }^{5}$ Which shows such pattern, it is not impossible for the similar development pattern to occur with the recent space activities. Therefore, narratives on the development of a special law regime to regulate outer space activities are reasonable. Outer space treaties do not provide specific regulation on the involvement of corporations/civil enterprises in outer space activities. ${ }^{6}$

Studies of all the currently applied international treaties on outer space exploration and use show that the form of these treaties is government to government in nature, including in public laws. Concerning this, Priyatna Abdurrasyid stated, "Since activities in outer space have largely been governmental or intergovernmental in nature, the detailed infrastructure is required to regulate the private commercial use of outer space is subject to the rules established under International law and National laws. "7

\subsection{The Direction of Outer Space Regulation}

It is possible to say that the freedom to economically exploit outer space and celestial bodies is limited. Conversely, the ban on territorial rights acquisition from countries, Non-Governmental Organizations (NGOs), international organization and any power may add to the complexity of the matter. The concept of outer space exploration and resource exploitation should always be carried out for the benefit of humanity. Details of the regime to regulate outer space activities can still be formulated with practical limitations.

Due to development of the complexity of operations and technical issues the second world war, the government of the United States sponsored workshops on civil aviation after the war ended in 1943. These workshops strengthened the trust which has been firmly held by many countries that civil aviation must be organized on an international scale.

Article 96 of the Convention on International Civil Aviation 1944 strongly established fundamental rules on international civil aviation, as a specialized United Nations institution founded in 1947. The convention also enables International Civil Aviation Organization (ICAO) to adopt international standards and practices which are recommended in ensuring the highest conformity in international rules, standards, procedures, and organizations as well as organizations

\footnotetext{
${ }^{5}$ See Martono and, Amad Sudiro, Hukum Udara Nasional dan Internasional Publik, Jakarta: Rajawali Pers, 2012, p. 9-11

6 Agus Pramono, op. cit, p 56

${ }^{7}$ Priyatna Abdurrasyid, Mata Rantai Penerbangan Ilmu-Teknologi dan Hukum Kedirgantaraan Nasional Indonesia, Jakarta: Fikahati Aneska, 2011, p. 419.
} 
related to civil aviation. In the following decade, ICAO has become one of the most credible UN institutions.

The middle $20^{\text {th }}$ century saw many initiations of space programs which last over the next two decades. In the beginning, the United States took the lead, which was followed by Europe. However, in the development, Europe has taken the same important role alongside the United States in spacecraft launch for both scientific and commercial interests. The development of outer space programs in the $20^{\text {th }}$ is characterized by global outer space industry which involves traditional outer space powers and various stakeholders from corporations and governments all over the world. The distance between outer space and geosynchronous orbit became closer, connected by military and commercial activity on the surface of the Earth, while governmental outer space programs were focused on distant objects, interplanetary explorations, and scientific pursuit.

Some factors has contributed in leading the world into a new outer space century, among which are: ${ }^{8}$

a. Outer space technology and services which spread all over the world;

b. Tendency of the global economy, and;

c. Dramatic strategic, economic, political and social changes following the end of the cold war.

Since the early decade of outer space introduction, the number key players namely the military, commercial operators and specifically private corporations has increased significantly and is new players are expected to join the development in the future.

The number of nations with the capacity to launch unmanned orbital craft to outer space ${ }^{9}$ Also has been growing as many nations have successfully increase their technological capacity. Also, international operators providing land and sea-based launch services have also taken part in outer space explorations. At the time this paper is written, 18 countries had attained the ability to commence sub-orbital flight. In February 2009, Iran launched its first orbital satellite; North Korea financed its Intercontinental Ballistic Missile Program, of which technology can be used to launch a satellite. In December 2010, approximately 50 countries had open access to outer space with launch capacity ${ }^{10}$ which was developed by their respective people in cooperation and development with other countries in the form of orbital assets management.

This revolution is a fast-paced change among different principles and interests in military

\footnotetext{
${ }^{8}$ Stephan Hobe in Annals of Air and Space Law, McGill University, Canada, 2007, p. 117

${ }^{9}$ Ibid

${ }^{10}$ Ibid

362
} 
and commerce, between private and government ownership and issues which are domestic and international. We are facing with a new regulation based on historical condition, which has never been seen before. Therefore, it is important to keep in mind that the adoption of applying solution models which are more likely to succeed in the past may not be the best option, or that the economical or holistic environment is in different perspective without regard to future implications.

The new age of outer space or "new outer space" $\mathrm{era}^{11}$ is dramatically different from the era which we have just left behind. Firstly, there is an increase in private funding in an organic manner. Secondly, space exploration will be so prominent in the international narrative, that it may blur the lines of ownership.

It is interesting to note that in 2003, China became the third country after Russia (formerly the USSR) and United States to develop the capacity to send a man to outer space. After successfully launching an unmanned mission to the moon in October 2008, India announced plans to initiate a manned space program to be launched in 2014, and first outer space landing in 2020. At the end of 20U, Chinese space station had entered orbit.

At the beginning of space exploration era programs developed by either the United States or the USSR were mostly geared towards military rather than scientific or commercial interest. The first man to enter the outer space was a USSR Air Force Major Yuri Alexeyevich Gagarin on 12 April 1961. The Redstone Mercury rocket of the United States launched Alan Bartlett Shepard to its first sub-orbital flight, of which itself a product of US Intercontinental Ballistic Missile development program.

The technical aspects of spacecraft resulted from military the workshops took form in projects such as Boeing X-20 Dyna-Soar of the United States Air Force (USAF) in the early 1960s. The research and construction of International Space Station (ISS) such as Manned Orbital Laboratory (MOL) and ALMAZ can be traced back to military programs. In 1963, USAF initiated the development of MOL, which was then canceled. The USSR responded by the creating the ALMAZ program, which was a series of military space stations. ${ }^{12}$

Through agreements between the United States and the USSR, an international pact on orbital surveillance by foreign satellites have been deemed acceptable and is believed to be able to build and verify intelligence on weapons. Military outer space programs are indicated in almost all of the uses of satellites known today, including those in flight and navigation, telecommunications and meteorology. For example, the commercial use of (Global Positioning System) GPS 
navigation system started in the United States in 1983, following the tragedy in which a Korean airplane was shot down by Russian air force after it accidentally wanders into the Russian airspace. Then US President Ronal Reagan issued an order to the USAF to allow access to the existing GPS signal for civil aviation as a secondary means of air navigation. Up until that point, the aforementioned GPS system is exclusively used by the United States for military purposes. ${ }^{13}$

The use of satellites for military purposes became a routine after the establishment of outer space treaty in 1967 . Hence, with peace as the main principle of outer space uses, military satellites had become an inseparable and integral part of the defense for both the United States and the USSR.

In the 1990s, the use of outer space assets as an integral component started from military plans. The Gulf War in 1991, codenamed Operation Desert Storm, is recorded as the first airspace-outer space war, saw the first utilization of the US air superiority assets with full range as active support for the real combat on the ground.

The event showcased the rapid development and advancement in outer space technology and proper use of international legal instruments as a facility with precise indicators in its utilization so that peace may be attained and to ensure that such uses benefit mankind.

International airspace and outer space laws consist of some treaties and jurisprudences, which today had been shown as two different and separate legal regimes despite binding "similar affairs" that is flight. Meanwhile, the history and development of outer space journey more clearly show the separation between the two jurisdictions. Today the rapid technological development and advancement in aviation have brought the two jurisdictions closer than ever before.

Although the exploration of outer space, even land, is traditionally linked with the interest of the government, technological development has allowed private corporation, local government (such as Florida, New Mexico and California with their commercial outer space activities centers), international consortium (such as the European Space Agency), as well as countries with little to capacity for outer space activity in the past to take part in the endeavor. Including in this evolution is the development of hybrid spacecraft which can traverse airspace and outer space territories. Today, commercial enterprises have begun to lead the development of flight and orbital systems of spacecraft, often in partnerships with international conglomerates to create multi-national spacecraft. In the past, only a few countries had the capacity of running such programs.

Besides, the hybrid spacecraft has the capability of both sub-orbital and orbital flight like that of any modern spacecraft. However, the key technology to this modern spacecraft is its 
capability to return to Earth (or to move into another orbital location) once it has completed its mission. Although the technology that enables a spacecraft to perform transition between orbits easily may not be available until a few decades in the future, the prototype for such spacecraft has been developed meanwhile science and technology keep advancing. For instance, the new US Space Shuttle and the experimental sub-orbital shuttle SpaceShipOne are capable of both sub-orbital and orbital flight. Since these new spacecraft, and possibly future spacecraft, transcend the borders between sub-orbital and orbital space, they pose legal dilemma which we will face in the future: to distinguish the two vehicles and how to apply two different, yet currently existing law regimes to regulate such issue.

Since the beginning of outer space flight and exploration in the 1950s, the demarcation between airspace and outer space territory has always been debated with no significant consensus reached. Based on the currently applied legal regime, all flight within the Earth's atmosphere falls under the "Aviation Law" regulation; and if such flight enters international airspace or waters, then it falls under the jurisdiction of international aviation law. Flight missions to outer space are generally regulated under the "Outer Space Law."

Since there is no academic measure on the demarcation of air space and outer space which is conclusively agreed upon, two ideas in such boundary have been put forth. Experts in support of the concept of "area" (or spatial) demarcation prefer to draw a clear line between the two spaces. The boundaries between airspace and outer space must be determined in the shortest amount of time, and the resulting demarcation line must apply forever since there are two different legal regimes regulating the activities in their respective spaces. The proponents of spatial demarcation hope to clearly identify the boundaries of the airspace of each sovereign nation and free outer space territories. On the other hand, experts in favor of "functional" concept believe that airspace and outer space territories are interlinked and should be regulated based on the activities occurring in the area; non-orbital flight should be regulated under aviation law, and outer space flight should be regulated under outer space law. Since the agreement on the demarcation between airspace and outer space has yet to be reached, proponents of this concept focus on the destination of the flight as the basis to apply the relevant law, instead of the arbitrary demarcation.

Recent technological development and more participation from private industries in outer space exploration and use increases the possibility for the creation of a vehicle with capabilities to traverse the lower part of the Earth's atmosphere (traditionally referred to as airspace) yet also capable of mesospheric and thermospheric flight (which may fall under the realm of outer space both in spatial and functional concepts). With such flight capacity, normal flight of the vehicle 
covers only the traditional airspace but, due to its ability to climb and maintain flight over the Earth's atmosphere, this kind of vehicle may be categorized as a spacecraft. Since it is possible to perform both sub-orbital and orbital missions using this vehicle, the regulation for such vehicles can be dilemmatic; whether its operations, missions and crews fall under the regulation of airspace and/or outer space laws.

Although airspace and outer space travel were enabled by the technological invention of the $20^{\text {th }}$ century, many countries understand this capacity through a long history and roots of ideas on national sovereignty and the concern of responsibilities that comes with it. Recent aviation laws have gone through modernization, ${ }^{14}$ Particularly in the regulations which hold air transport companies liable for any aviation incident that it suffers meanwhile abiding rules and regulations providing protection and tight requirements of airspace belonging to a sovereign nation. On the other hand, outer space laws are still disputed since it is difficult to impose responsibility for the damages which may occur on earth and in outer space, yet at the same time admitting that freedom in the outer space territory is jus cogens in nature.

\subsection{Regulation of Global Dynamics}

Limitations in aviation and outer space regulations may be imposed to commercial activities, yet their imposition may be indirect and national law-oriented in nature. This reality is certainly unsatisfactory, since it cannot provide adequate stimulus for the development of the commercial activities themselves, considering the number of limitations which may be put into place by certain countries. Also, excessive protection which may be imposed by certain countries will dampen the spirit of free competition.

Based on the discussion above, various alternative concepts are offered as the answers to legal challenges arising from the development in the commercialization of outer space activities. One suggested alternative is the institutionalization of a legal regime specific in regulating the use of outer space, both by governments and non-governmental entities. This concept renders a government out of power (de line imperi) and treats it as an entity involved in a trade activity (de jure gestiones), an equal position before the law as any entity bound by said law. ${ }^{15}$ The role of regulations in such trade laws is vital as legal foundations in the institutionalization of a special legal regime regulating outer space commercial activities, considering the unique nature of outer space commercial activity itself.

\footnotetext{
${ }^{14}$ Convention for the Unification of Certain Rules Relating to International Transportation by Air, 28 May 1999, ICAO document 9740 (effective 4 November 2003) [hereinafter referred to as Montreal Convention]

${ }^{15}$ Annals of Air and Space Law, McGill University, Montreal, Canada, 2005, Voll XXX, Part II, p. 593 
There are several legal issues related to rights and obligations of the parties involved in outer space commercial activities which require further clarification and elaboration, including: ${ }^{16}$

a. Systems and principles of liabilities, both inter-party and third-party liabilities.

b. Issues concerning international contracts, including bilateral, between governments and non-governmental entities, or between other legal subjects.

Other than the laws regulating liabilities among those involved in outer space commercial activities, there needs to be support from international public regulations such as a formulation of "International Code of Conduct." Many such "Code of Conduct" has been applied in other activities, for example, the "United Nations Code of Conduct for Liner Conferences" which has successfully increased the role of "liners" from developing countries in the international maritime transportation activities.

The aim of using the moon may also be the subject of our presence in outer space. This aim may materialize as demand for land ownership in the moon for those interested. Such discourse will be analyzed through the lens of legal regime established in the Space Treaty 1967. Several instruments of the lunar treaty may be prominent in the international level since the treaty represents practices of governments as an important tool of interpretation based on Article 31 Paragraph 3 of the Vienna Conference on International Treaties.

The discussion based on Space Treaty 1967 will be challenging considering that the treaty itself was established 49 years ago. At the time the treaty was signed, specific and private use of the moon seemed to be insignificant. The following discussion will attempt to interpret contents of Space Treaty 1967 in relation to the kind of lunar use and lunar area permitted based on the treaty.

Article 1 Paragraph 2 of Space Treaty 1967 stated that it permits all of this instrument free exploration and use of outer space, the moon and other celestial bodies. The article only explicitly mentions a sovereign state with no specific qualifications of the said "use." To clarify the issue, this discussion will highlight the proper definition of the term "use" in the article and then discuss the central issue of whether the stated sovereign countries are the sole holder of the right to the use of outer space. Article 1 Paragraph 2 of Space Treaty 1967 is specifically related to the free use of outer space for all countries. The term "exploration" means activities aimed at scientific investigations and discoveries. The point of debate here is whether the term "use" can only be applied to uses in the spirit of exploration or it can also be broadened to include commercial enterprises.

In accordance to Article XXXI of Vienna Convention 1969, an agreement must be ${ }^{16}$ Susan Trepezynski, The Benefit of Granting Immunity to Private Companies Involved in Commercial Space
Ventures, Annals of Air and Space Law, Montreal: McGill University, 2006, p. 384 
appropriately interpreted and faithfully defined by assigning meaning that is common to the terms used in their respective context and by considering the objectives and aims. The word formations in Article 1 Paragraph 2 of the Space Treaty 1967 is clear. What can be seen from the article is that the phrase "exploration" and "use" is written, instead of just "exploration." This shows that the term "use" has a broader meaning than just exploration. This frame is meant to be carried out in a mutually beneficial agreement. It has been specifically stated in a United Nations declaration on international cooperation in outer space exploration and uses that such efforts must be beneficial to all countries, with special considerations for developing countries. Also, there needs to be an emphasis on the term "use" to include commercial use of outer space.

The inclusion of commercial activities in the Space Treaty, as stated by the United States in 1977, as a respond to Bogota Declaration, ${ }^{17}$ even if commercial uses are not explicitly stated in Article 1 Paragraph 2. The absence of explicit statement regulating commercial use of outer space can be interpreted as permission of such activities within the boundaries of outer space.

All in all, there is a strong burden of proof in support of the view; that the exploration and the use of outer space include such activities which is commercial in nature.

Another discussion pertains to the issue whether or not the term "use" in the treaty includes the interpretation of extraction of natural resources, such as stones and materials from the moon, for commercial purposes as definite commercial use. Several views on such activities may not fall into the freedom of exploration and use pursued in the Article I Paragraph 2 of the Space Treaty 1967. In this sense, it would seem to be logical to identify the term "exploitation" or "use" of nature into the background that it is mentioned separately from the term "exploration."

In relation to this, United States General Assembly (UNGA) Resolution 1348 (XIII) year 1958 established an ad hoc committee on the peaceful use of outer space had emphasized the term "exploration" and "exploitation" of outer space. Similar terms are also used in UNGA Resolution 1472 (XIV) year 1959 which established the committee on peaceful use of outer space, while UNGA Resolution 1721 (XVI) year 1961, the predecessor to the Space Treaty 1967, replaced the term "exploitation" with "use". Hence, both term can be interpreted as referring to the same activity. An indicator to this was the Ad Hoc Committee report 1959, ${ }^{18}$ in which the term "use" was used, which predicted the prospect of human settlement with a clear implication that such event will require some exploitation of natural resources. However, there is disagreement on the precise meaning of the word "use" in the negotiation process written in Space Treaty from most delegates. Practices of countries following the establishment of Space Treaty suggested that the

17 Priyatna Abdurrasyid, Op. Cit, p. 226

18 Ibid

368 
term "use" include exploitation of resources from outer space. Therefore, resources exploitation in outer space, including on satellites any other celestial bodies, at least by technologically advanced countries like the USA, tend to agree with including exploitation in interpreting the term "use."

However, Article I Paragraph 2 of the Space Treaty 1967 do not explicitly state permission to exploit natural resources, thereby making the regulation of such activity problematic; whether extraction of natural resources from the moon or other celestial bodies can be considered as exploitation. However, there are several reasons which support the public availability of such resources, once, in the debate between negotiators of Space Treaty. It was believed that res communis principle applies to the opportunities and further coverage in outer space exploitation, use, and extraction of resources. ${ }^{19}$ At the same time, Article II of the Space Treaty rejects the principle of res nullius. Furthermore, the current international practice of outer space use and exploitation have been carried out by the principle of res communis. ${ }^{20}$ Another argument is based on the fact that Article II of the Space Treaty equally emphasizes the phrase “...outer space, the moon, and other celestial bodies...". If natural resources are not assumed to be covered by this article, then the application of a prohibition added in Article II of the space treaty on the availability of natural resources will be excessive.

Several things need to emphasize here. Firstly, Article II of the Space Treaty must be viewed clearly against the background of previous regulations of Conventions on Outer Space, which is stated in Article IV of the Antartic Treaty 1959. In the second paragraph of the article, there is a clearly established regulation which concerns the use of territorial sovereignty.

It is interesting to note that the United States and USSR suggested limitations for outer space treaties based on national sovereignty claims, which clearly influenced by the Antartica Treaty. ${ }^{21}$

\section{Conclusion}

The current legal regime namely Space Treaty 1967 does not prohibit exploration and use of outer space natural resources. The objective of outer space legal regime is to distribute the result of such endeavors for the benefit of all. With actual limitations, exploration and use of outer space resources may continue to be carried out. The use of outer space resources must be in line with the spirit of the legal regime in the framework of international community cooperation for the benefit

\footnotetext{
${ }^{19}$ Ranjana Kaul, Control of Space Assets-Ethics in Diplomacy in Annals Air and Space Law, McGill University, 2006, p. 450-451.

${ }^{20}$ Ibid

${ }^{21}$ Priyatna Abdurrasyid, Op. Cit, p. 220.
} 
of all including the operation of private satellites.

The development of outer space law must take place organically. The scientific uncertainty in many fields and the rapid technological development create challenges in establishing international treaties in that the treaties themselves may not cover contemporary issues. The most suitable law to regulate outer space territory is a general law. Its environment is very dynamic and rapidly changes, filled with uncertainties and possibilities, yet is in need of regulation with the spirit of freedom. In this sense, the process by which the contemporary outer space treaty has been formulated is on the right direction, since it leaves space for future development in the field to be covered. 


\section{References}

Agus Pramono, Dasar-dasar Hukum Udara dan Ruang Angkasa, Bogor, Ghalia Indonesia, 2011. Convention for the Unification of Certain Rules Relating to International Transportation by Air, 28 Mei 1999, dokumen ICAO 9740.

Hikmahanto Juwana, Hukum Internasional dalam Perspektif Indonesia sebagai Negara Berkembang, Yarsif Watanpone, 2010.

Martono dan, Amad Sudiro, Hukum Udara Nasional dan Internasional Publik, Jakarta: Rajawali Pers, 2012.

Priyatna Abdurrasyid, Beberapa Bentuk Hukum sebagai Pengantar Menuju Indonesia Emas 2020, Jakarta: Fikahati Eneska, 2008. , Mata Rantai Penerbangan Ilmu-Teknologi dan Hukum Kedirgantaraan Nasional Indonesia, Jakarta: Fikahati Aneska, 2011.

Stephan Hobe dalam Annals of Air and Space Law, McGill University, Canada, 2007.

Susan Trepezynski, The Benefit of Granting Immunity to Private Companies Involved in Commercial Space Ventures, Annals of Air and Space Law, Montreal: McGill University, 2006. 